\title{
Pelatihan Pengembangan Sistem Aquaponik Budikdamber Untuk Meningkatkan Ketahanan Pangan dan Kecerdasan Ekologis Masyarakat
}

\section{Gilang Mas Ramadhan}

STKIP Bina Mutiara Sukabumi

gemilanggarda@gmail.com

\begin{abstract}
Abstrak
Dewasa ini pemanfaatan lingkungan yang baik dapat menjadi salah satu akses untuk mencapai kesejahteraan hidup, guna menghasilkan produktifitas yang teraktualisasi dalam perilaku masyarakat yang aware akan lingkungan terutama dalam memanfaatkan sumber daya alam lokal, begitupun masyarakat desa Kutasirna, tepatnya warga rt 12 dan 13 di Kecamatan Cisaat, Kab. Sukabumi, daerah dengan potensi alamya di bidang budidaya ikan air tawar dan pertanian, namun fakta di lapangan menunjukan warga belum terlalu memaksimalkan potensi tersebut, selain itu kesadaran warga akan pentingnya ketahanan pangan dengan cara system tanam aquaponik dan hydroponik masih kurang, juga belum ada wadah terorganisir dalam memasarkan hasil perikanan dan pertanian, oleh karena itu perlu adanya upaya pemberdayaan serta pendampingan kepada masyarakat, agar lebih produktif. Adapun metode pelaksanaan pengabdian pada masyarakat ini dimulai dengan tahap sosialisasi mengenai Inovasi dalam sistem tanam aquaponik kemudian tahap pembangunan sistem tanam aquaponik, tahap manajemen kelembagaan masyarakat dan diakhiri dengan evaluasi serta monitoring. Dan hasil dari pengabdian ini sendiri adalah semakin meningkatnya kecerdasan ekologis yang terimplementasi pada pengetahuan, sikap dan keterampilan masyarakat setempat. Setelah program pengabdian ini dilaksanakan, masyarakat kini memiliki kesadaran akan pentingnya ketahanan pangan, keterampilan dalam sistem tanam aquaponik serta keterampilan membuat olahan makanan ikan lele dari hasil budikdamber yang selanjutnya dapat dipasarkan di platform aplikasi kutamart, sehingga sektor kewirausahaan dan ekonomi kreatif dapat tumbuh dan berkembang di desa Kutasirna ini, kemudian diharapkan dapat menciptakan sinergitas antara masyarakat dan pemerintah dalam upaya menciptakan SDM yang unggul dan mampu bersaing di era digital melalui kolaborasi dengan stakeholder, pemerintah setempat dan UMKM yang ada.
\end{abstract}

Kata Kunci: pengabdian masyarakat, ketahanan pangan, aquaponik

\section{Pendahuluan}

Pemanfaatan lingkungan yang baik dapat menjadi salah satu akses untuk mencapai kesejahteraan hidup, lingkungan adalah tempat dimana terjadi kontak kehidupan yang bersinergis antara manusia dan alam yang keduanya akan saling mempengaruhi satu sama lain, dan diharapkan dapat berdampak positif dan menghasilkan suatu produktifitas yang teraktualisasi dalam perilaku masyarakat yang aware akan lingkungan. 
(Putri dkk, 2017). Begitupun dengan warga di Desa Kutasirna yang terletak di Kecamatan Cisaat, Kab. Sukabumi, daerah dengan potensi alamya di bidang budidaya ikan air tawar. di Kecamatan Cisaat sendiri terdapat kurang lebih 2.356.09o $\mathrm{m}^{2}$ kolam ikan air tawar yang resmi terdaftar dan tersebar di beberapa wilayah pengembangan dengan komoditas-komoditas ikan air tawar yang menjadi unggulan mereka. Dari aspek kondisi sosial masyarakat desa Kutasirna yang bermata pencaharian utama sebagai peternak ikan lebih sedikit dibandingkan dengan mata pencaharian peternak sampingan. Melihat kondisi gambaran umum di atas, didapati beberapa kendala utama budidaya ikan air tawar ini diantaranya adalah waktu dan biaya yang cukup tinggi. Walaupun mengalami kesulitan dan hambatan dalam pembudidayaan ikan, masyarakat masih mempertahankan pengelolaan budidaya ikan ini, Salah satu warga yang menjadi khalayak sasaran pada program pengabdian masyarakat ini adalah Saudara Hilman yang berasal dari warga Kp. legok inggris RT 13/05 Desa kutasirna, dari hasil wawancara dengan beliau didapati info bahwa memang masyarakat kutasirna pada khususnya belum maksimal dalam memanfaatkan potensi budidaya ikan ini, sehingga hasil yang didapat tidak begitu maksimal, menurutnya memang diperlukan inovasi dalam mengkombinasikan sektor budidaya ikan air tawar dengan sektor pertanian melalui sistem akuaponik ini. maka dengan menerapkan sistem tanam aquaponik ini diharapkan masyarakat memiliki pemahaman tentang ekosistem dan diharapkan muncul sikap empati yang tinggi terhadap segala bentuk jenis kehidupan, memadukan kecerdasan kognitif, social dan emosional, merasakan apa yang dirasakan orang lain dan menunjukan kepeduliannya terhadap lingkungan. (Goleman, 2010).

Hidroponik dan aquaponik sendiri merupakan metode bercocok tanam dengan menggunakan media tanam selain tanah, seperti batu apung, kerikil, pasir, sabut kelapa, potongan kayu atau busa sebagai pengganti tanah, yang dijadikan media pendukung akar tanaman dan perantara larutan nutrisi dapat digantikan dengan mengalirkan atau menambah nutrisi, air dan oksigen melalui media tersebut (Roidah 2014 ). Sistem tanam ini dapat diaplikasikan di perkotaan maupun di pedesaan yang hemat air dan tempat serta pemeliharaannya mudah dan dapat dipanen sepanjang tahun (Surtinah 2016). Adapun Secara sederhana, akuaponik dapat digambarkan sebagai penggabungan antara sistem budidaya akuakultur (budidaya ikan) dengan hidroponik (budidaya tanaman/sayuran tanpa media tanah). Perawatan hidroponik ini sangat mudah, karena tumbuhan, tanaman atau sayur-sayuran dapat tumbuh dengan mudah tanpa menggunakan tanah, hanya dengan talang air, botol-botol kemasan yang sudah tidak terpakai dan juga bisa memanfaatkan barang-barang yang sudah tidak diperlukan seperti ember, baskom dan sebagainya (Satya dkk, 2017).

Sistem ini mengadopsi sistem ekologi pada lingkungan alamiah, dimana terdapat hubungan simbiosis mutualisme antara ikan dan tanaman. Keunggulan sistem budidaya akuaponik diantaranya dapat diterapkan di pekarangan sempit, tidak memerlukan media tanam, pupuk, penyiraman, hemat air, sehat, memiliki nilai estetika tinggi, Jadi, akuaponik sangat prospektif untuk dikembangkan di tempat dimana air dan tanahnya langka serta mahal, seperti di wilayah perkotaan, di daerah kering, padang pasir, serta pulau-pulau kecil. Sistem akuaponik adalah kombinasi akuakultur dan hidroponik untuk memelihara ikan dan tanaman dalam satu sistem yang saling terhubung. Limbah yang dihasilkan oleh ikan digunakan sebagai pupuk untuk tanaman, akuaponik hemat energi, mencegah 
keluarnya limbah ke lingkungan, menghasilkan pupuk organik untuk tanaman (lebih baik dari bahan kimia), menggunakan kembali air limbah melalui biofiltrasi dan menjamin produksi bahan makanan melalui multi-kultur, membuat akuaponik pantas dikatakan salah satu model panutan untuk green technology.

Rochintaniawati (2016) menjelaskan beberapa keuntungan bercocok tanam secara hidroponik antara lain: tanaman terjamin kebebasannya dari hama dan penyakit, produksi tanaman lebih tinggi, tanaman tumbuh lebih cepat dan pemakaian pupuk lebih efisien, tanaman memberikan hasil yang continue, lebih mudah dikerjakan tanpa membutuhkan tenaga kasar, tanaman dapat tumbuh pada tempat yang semestinya tidak cocok, tidak ada resiko sebagai ketergantungan terhadap kondisi alam setempat, dan dapat dilakukan pada tempat-tempat yang luasnya terbatas. Meskipun begitu sistem budidaya aquaponik ini sangat bergantung pada air, dan air yang digunakan adalah air yang sudah diberi nutrisi lengkap untuk pertumbuhan dan perkembangan tanaman, aliran air harus dapat mengalir yang kecepatannya sesuai dengan kemiringan. Bersamaan dengan mengalirnya air maka kebutuhan oksigen pada media tanam akan tercukupi (Surtinah, 2016).

Sementara itu tujuan pengabdian masyarakat ini sendiri adalah meningkatkan kesadaran akan pentingnya menjaga lingkungan serta menjamin ketahanan pangan masyarakat yang dapat bermula dari rumah, selain itu masyarakat memiliki kompetensi ekologis, kompetensi ekologis dapat dicapai dengan mengembangkan kepekaan, kesadaran, pemahaman, pemikiran kritis dan menemukan solusi pemecahan masalah lingkungan. Selaras dengan itu center for ecoliteracy (2004) mengembangkan satu set kompetensi inti kecerdasan ekologis, berupa 1) learning to know, 2) Learning to be, 3) learning to do dan hubungan manusia dengan alam sekitar (Learning to live together). Dan agar lebih terorganisir pembuatan TIM kelembagaan masyarakat juga penting seperti terbentuknya tim kutaponik dan kutasnack disertai dengan pelatihannya maka masyarakat akan diberikan pengetahuan tentang bagaimana cara menjalankan organisasi dalam tim terutama dalam rangka menciptakan masyarakat yang lebih produktif lewat hasil aquaponik berupa sayuran dan olahan ikannya. dengan terciptanya olahan atau produk baru maka diharapkan akan muncul peluang ekonomi baru sebagai mata pencaharian masyarakat dalam rangka menggerakan sektor ekonomi kreatif masyarakat setempat. Karena masih ditemukan pola pikir masyarakat seperti kurangnya pengetahuan masyarakat terhadap pilihan usaha ekonomi kreatif berbasis sumber daya local, Kurangnya kesadaran masyarakat akan potensi kegiatan kewirausahaan dengan menggunakan bahan dasar lokal (Hurley, Pardey, Rao, \& Andrade, 2016).

\section{Metode Pelaksanaan}

Lokasi pengabdian pada masyarakat ini sendiri berada di Desa Kutasirna Kecamatan Cisaat Kabupaten Sukabumi. Peneliti mengambil lokasi penelitian budidaya ikan air tawar di daerah ini karena Kecamatan Cisaat memiliki jumlah budidaya ikan air tawar yang paling tinggi dan banyak di Kab. Sukabumi daripada Kecamatan lainnya, pengadian dilaksanakan pada bulan september sampai november 2020, meskipun dilakukan di masa pandemi covid 19. Tim pengabdian selalu memperhatikan protokol kesehatan dengan tahap metode pelaksanaan sebagai berikut: 1) Tahap sosialisasi mengenai Inovasi dalam sistem tanam akuaponik; 2) Tahap pembangunan sistem tanam akuaponik dengan 
menggunakan peralatan yang sudah disediakan, berupa ember besar, paralon, bibit ikan dan bibit tanaman, serta peralatan lainnya; 3) tahap manajemen kelembagaan masyarakat melalui pembentukan tim pengelola agar masyarakat lebih terorganisir serta demi menjaga kesinambungan program ini; 4) tahap evaluasi untuk mengetahui kekurangan dalam pelaksanaan program; dan 5) tahap monitoring agar program pengabdian ini memiliki prospek yang berkelanjutan dan berkesinambungan.

\section{Hasil dan Pembahasan}

Melalui pembuatan dan pengembangan sistem tanam aquaponik budikdamber ini diharapkan masyarakat memiliki kesadaran akan ketahanan pangan yang dapat dimulai dari lingkungan sekitar serta mampu memanfaatkan potensi lokal yang ada. Program pengabdian pada masyarakat ini bertujuan agar masyarakat sasaran di Desa Kutasirna mendapatkan pemahaman yang lebih tentang metode sistem tanam modern yang berusaha mengkobinasikan sektor pertanian dan perikanan melalui sistem tanam aquaponik dengan media budikdamber, adapun hasil pengabdian diuraikan di bawah ini.

\section{Aspek Pengetahuan}

Pada proses transfer pengetahuan terkait dengan berbagai macam tekhnologi dan inovasi pembuatan media dan tata cara penanaman akuaponik dilakukan kegiatan sosialisasi pada tanggal 5 september 2020 di balai desa kutasirna dengan menayangkan tayangan video seputar sistem tanam hydoponik dan aquaponik selanjutnya masyarakat diberikan pelatihan secara langsung melalui demonstrasi pembuatan media dan tata cara hidroponik sayuran organik yang dikombinasikan dengan budidaya ikan, yaitu melalui sistem aquaponik melalui media budikdamber ikan lele, Teknis pembuatan budikdamber lele sendiri adalah sebagai berikut; (a) menyiapkan media ember yang telah diatur sirkulasi air dan tempat untuk tanaman hydroponik di atas ember sebagai media tanam sayuran; (b) menyiapkan media hidroponik dengan menggunakan gelas plastik bekas minuman (c) menyiapkan media hidroponik lainnya menggunakan pipapipa yang disambung dengan pola berbeda. Pipa tersebut digunakan sebagai tempat untuk memasukan benih. Sementara untuk tata cara penanaman hidroponik yang dilakukan sebagai berikut; (a) pembibitan dengan memilih bibit yang berkualitas; (b) penyemaian sistem hidroponik menggunakan bak plastik yang berisi campuran pasir halus, sekam bakar, kompos dan pupuk kandang dengan perbandingan 1:1:1:1. Media tanam yang digunakan sabut kelapa dan sekam bakar. Kemudian mengisi polybag dengan media tanam yang sudah siap; (d) membuat green haouse dari rangka bambu; (e) memberikan pupuk yang kaya unsur hara makro dan mikro; ( $f$ ) melakukan perawatan tanaman seperti pemangkasan, pembersihan gulma, penyemprotan pupuk dan lain sebagainya (Roidah dan Ida Syamsu, 2014)

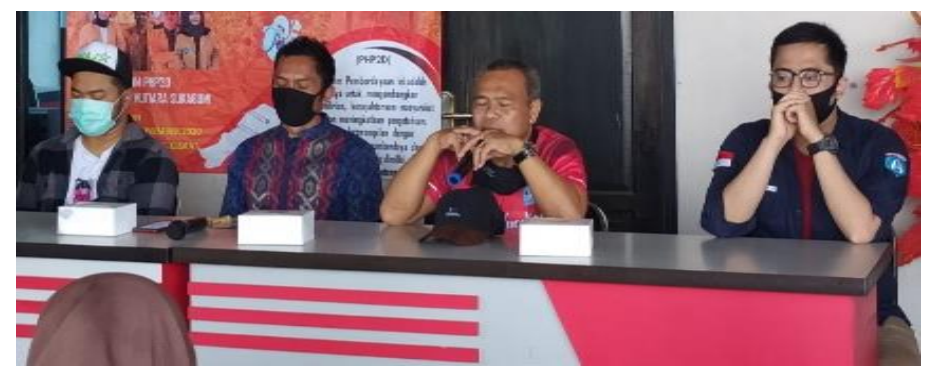

Gambar 1. Sosialisasi 


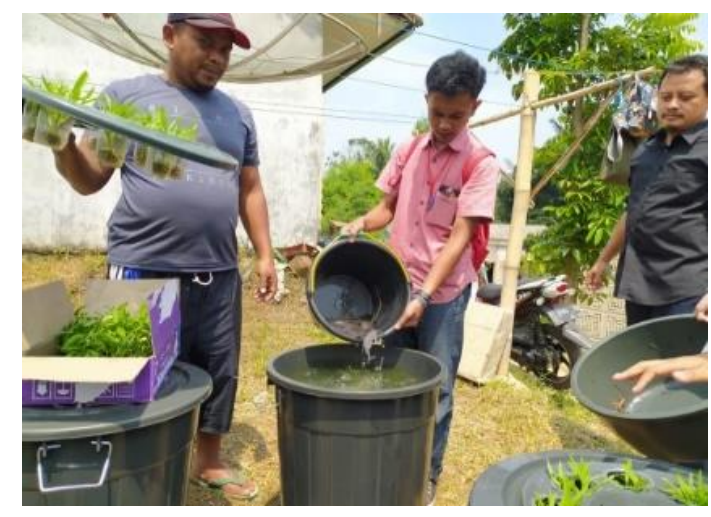

Gambar 2. Demonstrasi

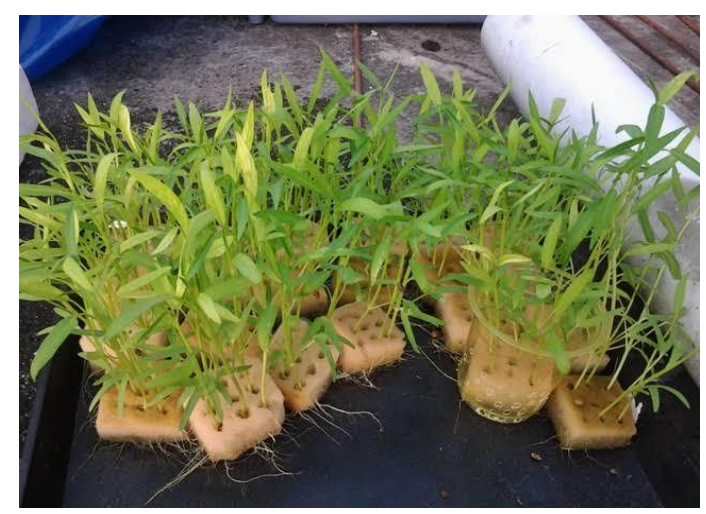

Gambar 3. Pembeniha

\section{Aspek Sikap}

Pada aspek sikap ini masyarakat telah memiliki kesadaran akan pentingnya mengkonsumsi makanan sehat serta mandiri akan stok pangan untuk kebutuhan konsumsi rumah tangga atau dalam skala yang lebih besar untuk dijadikan lahan komersil. bercocok tanam dengan memanfaatkan sistem tanam ini memiliki banyak kelebihan sekaligus memudahkan masyarakat dalam bercocok tanam, karena bisa dilakukan di lahan sempit, dapat dilakukan di pekarangan rumah, di pekarangan tempat kerja, bahkan di lahan yang luas untuk skala tanam yang lebih besar. Dengan begitu kebiasaan positif semacam ini akan menjadi karakter yang melekat pada diri masingmasing individu dan diharapkan berlangsung secara kontinuitas dan dijadikan role models bagi warga sekitar lainnya. Berikut di bawah ini gambar aktifitas warga saat menerapkan sistem tanam aquaponik di sekitar pekarangan lingkungan rumahnya.

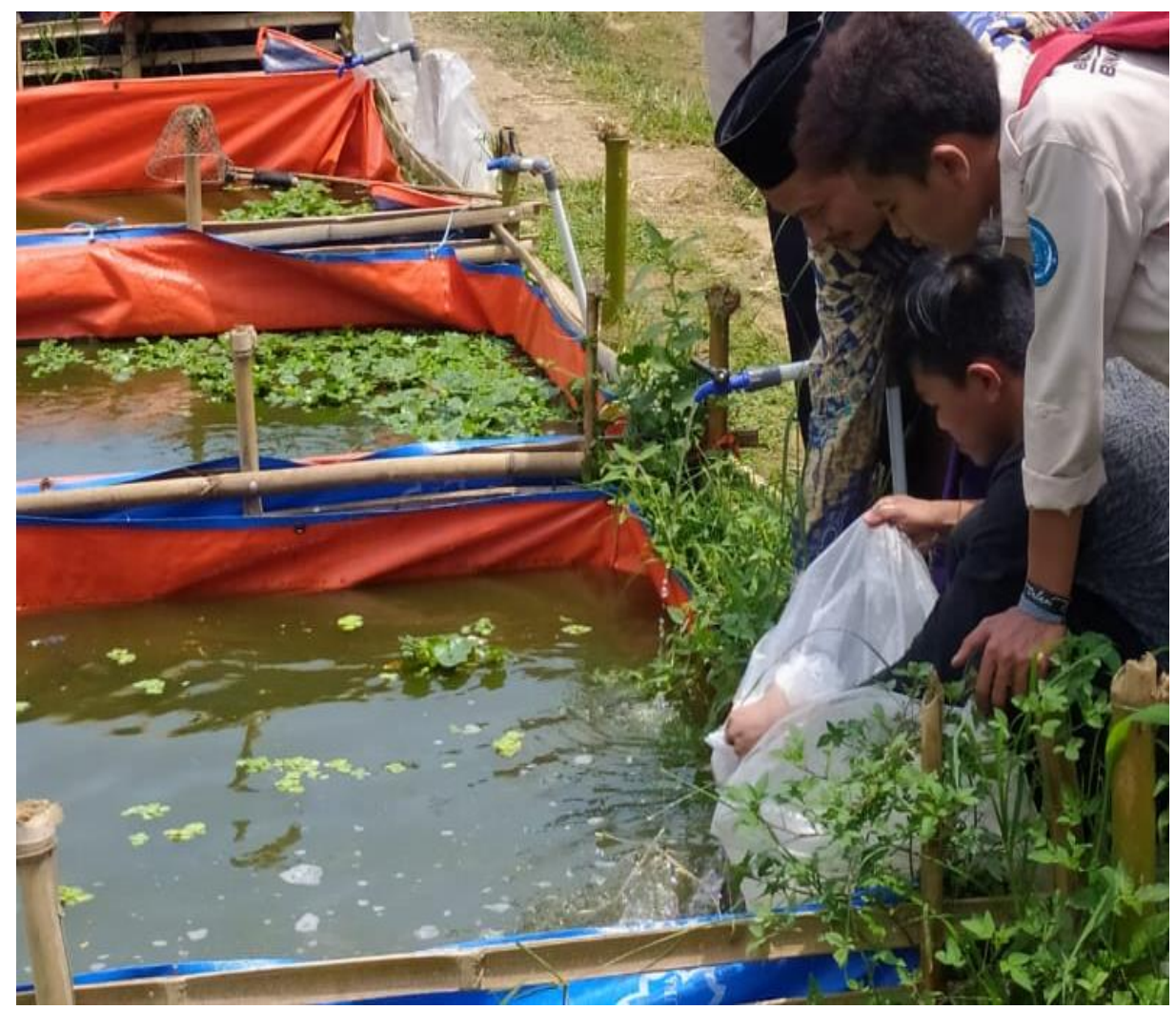

Gambar 4. Aktifitas tanam 


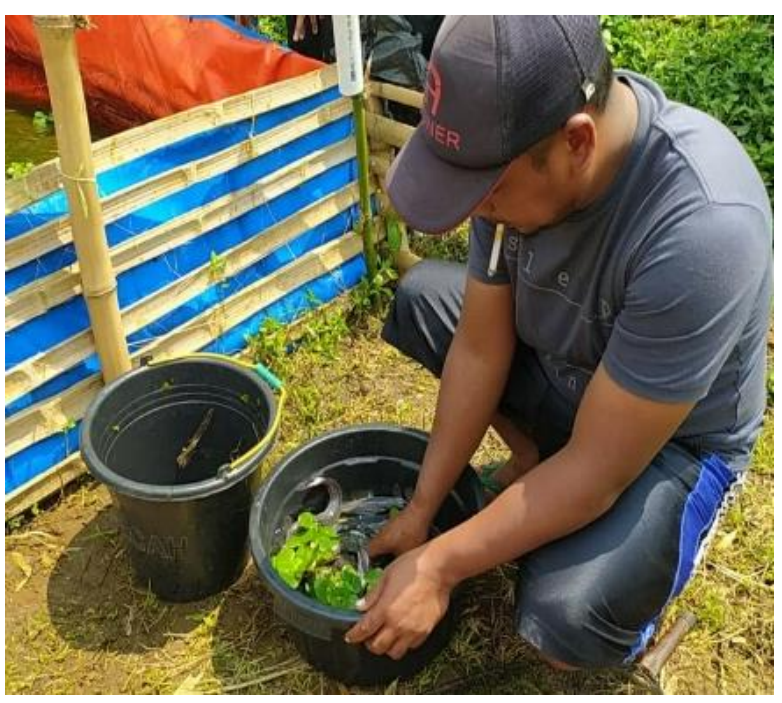

Gambar 5. Aktifitas tanam

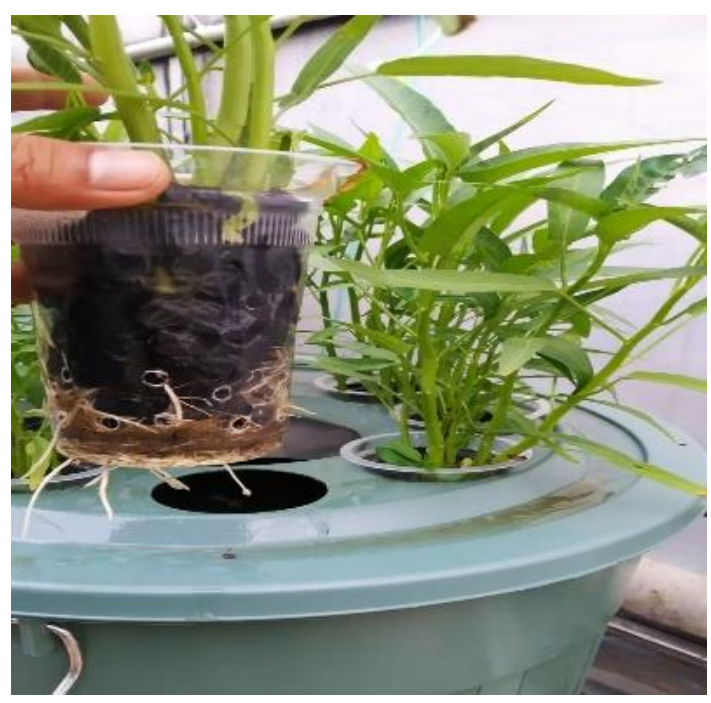

Gambar 6. Aktifitas tanam

\section{Aspek Keterampilan}

Pada aspek keterampilan masyarakat memiliki keterampilan dalam membuat media tanam akuaponik dari bahan-bahan yang sederhana yang dapat ditemui di sekitar lingkungan bahkan dapat berasal dari limbah plastik. Pada indikator selanjutnya dari segi perubahan fisik, masyarakat telah difasilitasinya dengan adanya rumah hydroponik dengan pengembangan sitem tanam Akuaponik, paling tidak untuk dapat memenuhi kebutuhan pangan sehari hari, selain itu diharapkan dapat muncul peluang baru dalam skala besar untuk dapat memproduksi sayuran hydroponik dan olahan makanan ringan berbahan dasar ikan kecil (Babyfish) berupa abon lele selain itu diharapkan terjalin kemitraan dengan beberapa kelompok tani atau agribisnis di sekitar sukabumi, misalnya dengan kelompok Sukaponik ataupun dapat bersinergi dengan para pelaku usaha untuk dapat ikut memproduksi sekaligus memasarkan produk snack cemilan babyfish dan abon ikan lele ini yang dihasilkan dari sistem tanam akuaponik, sehingga sektor kewirausahaan dan ekonomi kreatif dapat tumbuh dan berkembang di desa Kutasirna ini. Selain itu keterampilan manajer kelembagaan dapat dibangun lewat terbentuknya sebuah kelompok masyarakat yang bernama Kutaponik yakni sebuah kelompok masyarakat di desa kutasirna yang ke depan akan menghasilkan produk sayur hydroponik serta snack babyfish yang dapat dijadikan konsumsi sehat bagi masyarakat kutasirna pada khususnya dan masyarakat sukabumi bahkan Indonesia pada umumnya. Setelah proses pelaksanaan program binaan ini, diharapakan melalui pembinaan dari pemerintah desa setempat terdapat Program berkelanjutan yang saling bersinergis antara masyarakat, pemerintah desa dan para pelaku usaha untuk mengembangkan berbagai inovasi dalam sistem tanam akuaponik ini serta mampu menggerakan sektor ekonomi, diharapkan peran para pemuda milenial desa setempat mampu memberikan kontribusinya terlebih dalam memanfaatkan market place ( tokopedia, buka lapak dll) dalam proses pemasarannya juga bisa memaksimalkan aplikasi kutamart yang telah dibuat. Berikut di bawah ini produk kutasnack berupa abon lele dan aplikasi kutamart yang dapat mewadahi para UMKM dalam rangka memasarkan produknya. 


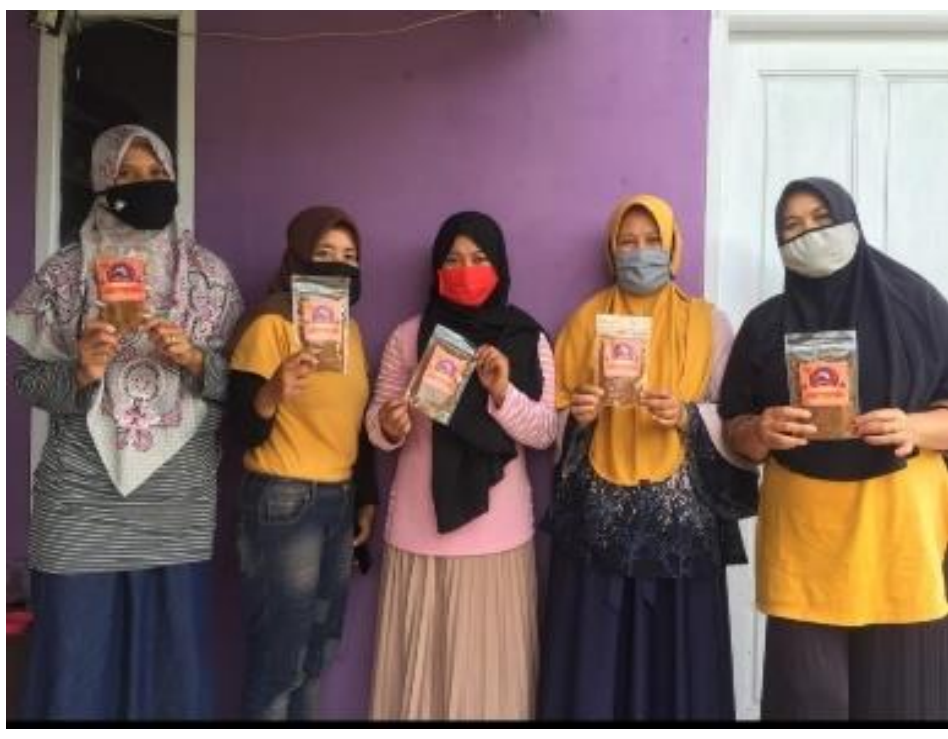

Gambar 7. Warga abon lele

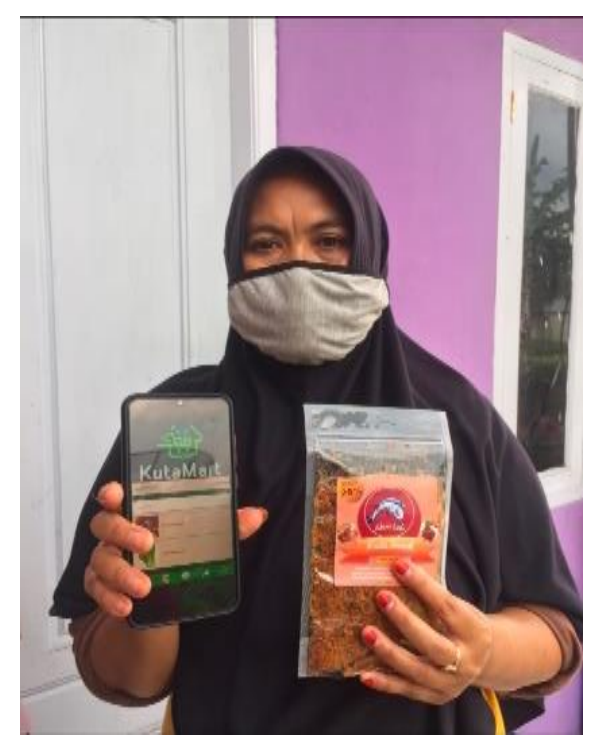

Gambar 8. Warga abon lele

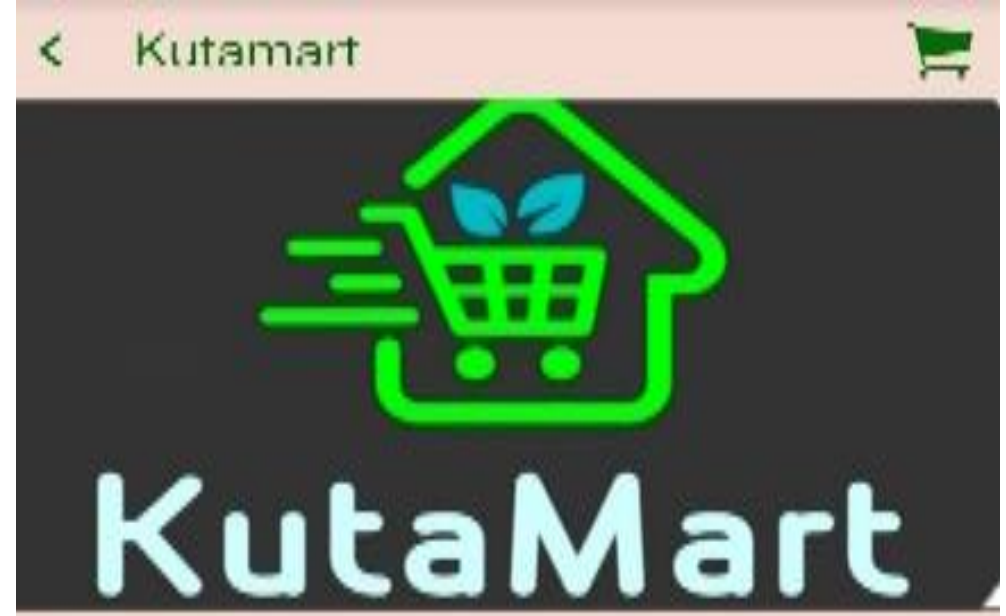

Kutamart

Cotri

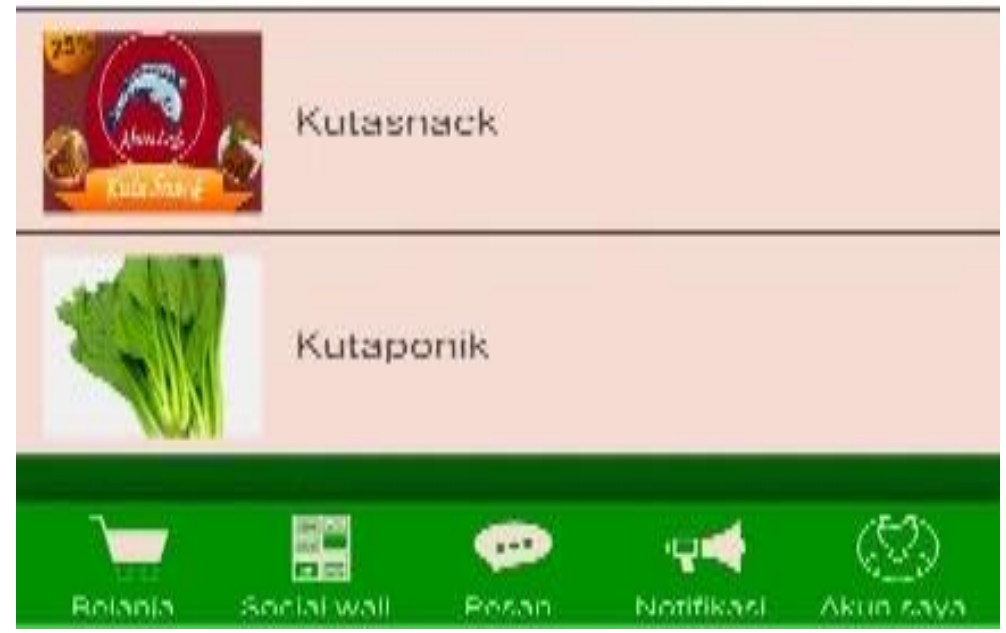

Gambar 9. Aplikasi Kutamart 
Dan berikut ini disajikan hasil pelaksanaan pengabdian yang telah dilaksanakan dalam bentuk data kuantitatif terkait dengan peningkatan kecerdasan ekologis masyarakat pra dilaksanakannya pengabdian dan pasca dilaksanakannya program pengabdian ini, terkait dengan kompetensi pengetahuan, sikap dan keterampilan. Pada grafik terlihat bahwa pra dilaksanakannya pengabdian kompetensi ekologis masyarakat masuk pada kategori cukup baik, dengan rata-rata 21 dari nilai maksimum 50, kemudian pasca dilaksanakannya program pengabdian rata-rata kompetensi ekologis masyarakat sasaran menjadi 43 berada pada kategori sangat baik, hal ini dapat membuktikan akan efektifitas pemahaman terhadap lingkungan memang harus aplikatif terutama dalam memanfaatkan potensi lokal masyarakat setempat, berikut data disampaikan dalam grafik di bawah ini.

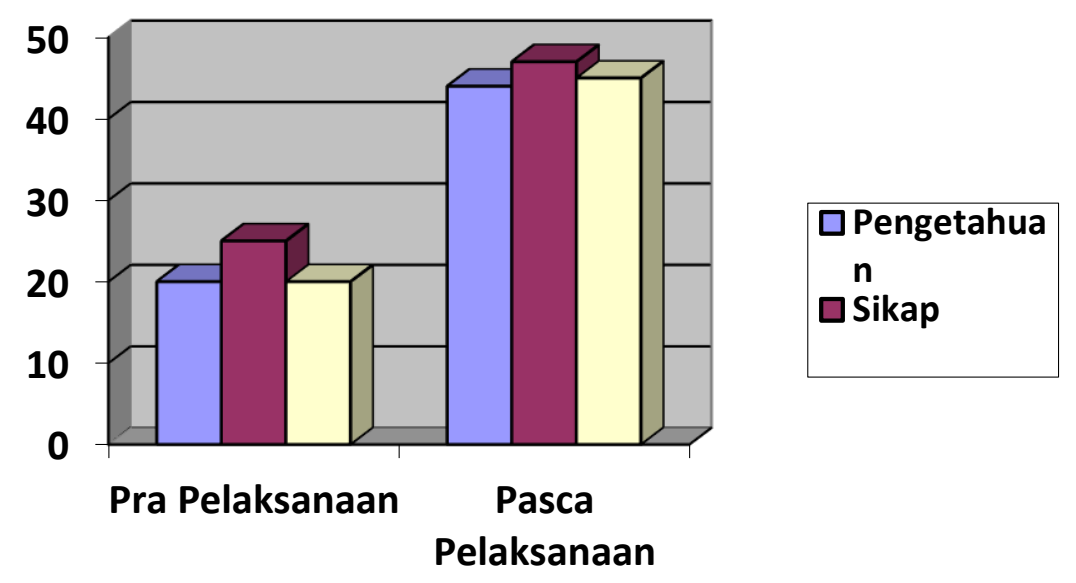

Gambar 10. Grafik Peningkatan ecoliteracy masyarakat

\section{Kesimpulan}

Berdasarkan hasil pelaksanaan pengabdian pada masyarakat ini dapat disimpulkan bahwa, Dengan dibangunnya sistem tanam aquaponik dan rumah mini hydroponik sedikit banyak memberikan pemahaman kepada warga sasaran dalam mengkombinasikan sektor pertanian dan perikanan sehingga masyarakat lebih aware akan pentingnya ketahanan pangan bisa dimulai dari halaman rumah masing-masing melalui sistem aquaponik dengan pemanfaatan budikdamber, selain itu dengan dibentuknya tim pengelola rumah hydroponik, pengelolaan dan perawatan sistem tanam aquaponik budikdamber akan lebih termanage dengan sistem yang telah dibentuk sehingga tercipta pengelolaan dan perawatan secara berkesinambungan, Dengan memanfaatkan akses tekhnologi yang terus berkembang, tim memfasilitasi warga dengan kehadiran aplikasi jual beli online kutamart untuk membantu warga dalam memasarkan produk lokal yang dihasilkan dari sektor pertanian dan perikanan ini, Potensi keberlanjutan program dapat didukung dengan terbentuknya tim Kutaponik dan kutasnack yang terdiri dari warga Desa Kutasirna, juga didukung dengan beberapa kerja sama, seperti dengan Instansi Pemerintahan Desa Kutasirna dan sukaponik serta beberapa jaringan wirsausaha yang ada di sekitar kab dan kota sukabumi Jabar. kemudian diharapkan dapat menciptakan sinergitas antara masyarakat dan pemerintah dalam upaya menciptakan SDM yang unggul dan mampu bersaing di era digital melalui kolaborasi dengan stakeholder, pemerintah setempat dan UMKM yang ada. 


\section{Ucapan Terimakasih}

Saya ucapkan terima kasih kepada kementerian pendidikan dan kebudayaan bidang kemahasiswaan yang telah memberikan support terkait dengan pelaksanaan pengabdian yang telah diselesaikan dengan cukup baik ini melalui sinergitas dengan masyarakat, mahasiswa dan stakeholder lainnya.

\section{Referensi}

Center for Ecoliteracy. (2004). Ecoliteracy competencies. [online] Diakses Dari http://www.ecoliteracy.org/publications/fritjop

Goleman, D. (2010). Ecological Intelligence How Knowing The Hidden Impacts Of What We Buy CCn Change Everything (Edisi Bahasa Indonesia). Jakarta:Gramedia Pustaka Utama

Hurley, T. M., Pardey, P. G., Rao, X., \& Andrade, R. S. (2016). Returns to Food and Agricultural R\&D Investments Worldwide, 1958-2015. InSTePP (International Science \& Technology Practice \& Policy center).

Putri, S. U., \& Nikawanti, G. (2017). Pengenalan Green Behaviour Melalui Ecoliteracy Pada Anak Usia Dini. Cakrawala Dini Jurnal Pendidikan Anak Usia Dini, 8(2). https://doi.org/10.17509/cd.v8i2.10538

Rochintaniawati, D. (2016). Hidroponik Sederhana. http://file.upi.edu/Direktori/FPMIPA/JUR._PEND._BIOLOGI/DIANA _ROCHINTANIAWATI/BIOLOGY_TERAPAN/HIDROPONIK_SED ERHANA.pdf

Roidah, I. S. (2014). Pemanfaatan Lahan Dengan Menggunakan Sistem Hidroponik. Jurnal BONOROWO, 1(2), 43-49. Retrieved from http://www.jurnalunita.org/index.php/bonorowo/article/view/14

Satya, M. T., Tejaningrum, A., \& Hanifah, H. (2017). Manajemen Usaha Budidaya Hidroponik. Jurnal Dharma Bhakti Ekuitas, 1(2).

Surtinah, S. (2016). Penambahan Oksigen pada Media Tanam Hidroponik terhadap Pertumbuhan Pakcoy (Brassica rapa). J. Bibiet 1(1), 27-35. 